\title{
Research on the construction of rural information network platform
}

\author{
based on Internet
}

\author{
Wei Zhao and Fangyun Li \\ Institute of Technology .East China Jiaotong University \\ Jiangxi Nanchang 330100
}

Keywords: information network; connotative urbanization policy guidance; financial support

\begin{abstract}
China's national conditions, to achieve the production method and the optimal urban lifestyle choice is connotative urbanization road. Network information service plays a positive role in promoting the realization of the ruralurbanization in connotation, the government should play a guiding andpromoting the function of public finance, construction of rural informationnetwork service.
\end{abstract}

\section{The connotation type development}

The realization of the city road into denotative and connotative in two ways, extensive city road refers to the large-scale investment, expansion or new cityand supporting facilities, public services, industrial and commercial enterprises, the realization of the rural labor transfer to the city, expanding the city population and geographic scope, reduce the rural population and geographic scope the traditional mode of agricultural production, so as to realize the modernization and traditional rural lifestyle socialization;connotation of city road is refers mainly by urban and rural development, thecity economic and social development in the advanced idea, system,technology, education and consumer fashion into the rural production and life, to achieve the traditional agricultural production the modernization of the traditional rural way of life and society, promote the comprehensive development of rural economy and society. The connotation type development mainly relies on to improve their own quality and reduce the cost, improve quality, improve efficiency, is quality benefit development mode, generally reflected in the people and things of their own efficiency, achieve the same money can play better benefit, is a benign development can be sustained,without increasing the funds investment to support normal development. The development road of connotation mainly through the deepening of reform, the internal vitality, enhance strength, improve competitiveness, in quantitativecause qualitative change process, realize the leaping development ofsubstantial. Compared the two, the connotation of urbanization road is more superiority, also is practical and feasible.

\section{Information network service in the rural city of connotation}

Mankind has entered the information society, information network intothousands of households, information network service can play a tremendous role in realizing the rural connotation in the process of city.

(1) through the information network service, farmers can choose the high-techcontent needed for agricultural production of agricultural machinery, seed,fertilizer and other auxiliary means of agricultural production, the realization ofthe modernization of agricultural production mode, greatly improve theagricultural productivity and the economic efficiency, increase the income of farmers. 
This is the best city to help the industry nurturing agriculture rural areas and measures, is also the connotation of urbanization is the most andachieve substantial performance of rural production development, wealthy life"solid foundation.

(2)Through the information network service, can make the traditional farmers did not come to the town and the realization of the social life of.

The infiltration of modern city life concept and mode of consumption to the countryside through information network service, so that the villagers in ideology, consumption habits, and other aspects of city leisure projects, so as to break some feudal superstition, discard the inherent customs, expand theirthinking, guide a farmer to consumer to a higher level of spiritual needs of the development, improve the lives of farmers quality, achieve "clean and civilized village". At the same time, the rural traditional provide for oneself, lifestyle changes, so that the life of the villagers rely on social operation, which is activein China consumer market, to promote the introduction of the development of rural commodity economy and market competition mechanism, the refinement of social division of labor in the rural management, improving the efficiency ofagricultural production, farmer's eyes open, to promote the "democratic management effectively".

(3) through the information network service, can make the rural share publicinformation resources development, education and personnel training, rural and city in the same information, policy, technology, resource utilization on the platform, realize the input equivalence, information symmetry, the policy of fair,science and technology application, make the rural resources reasonabledevelopment and utilization of the economy, the rural ecological environmentcan be protected, the development of basic social services to improve the quality and the rural population, the rural traditional mode of production and way of life changed.

(4) through the information network service, can improve the quality of ruralpopulation. About $64 \%$ of China's population in the rural areas, per capita arable land, unit labor productivity and the rate of output per unit of land is limited, the plantation industry growth space is very limited, which is the bottleneck to solve the "three rural issues". To enable farmers to get rich, toreduce the number of traditional farmers. However, numerous studies show that farmers' low quality has become their transfer of rural surplus labor to non-agricultural business and obstacles, make rural surplus labor and the"shortage of migrant workers" coexist. Therefore, the government vocational and technical training through the information network, improve the rural labor force and the basic quality of the technical level, is the best measure ofpeasant's non-agricultural.

(5) through the information network service, can promote rural industrial structure and its spatial distribution transformation to the rationalization andadvanced. Information network service can make the modern science and technology and modern production technology, agricultural biotechnology,modern information and modern management science to the agricultural production, the agricultural factor of production quality and elements of urbanindustrial production quality level increasingly close, to create conditions for the emergence of new green agricultural industry, agricultural specialization, a variety of professional agricultural management gradually scale, deep processing of agricultural products, the rapid development, the formation ofagriculture, industry and Commerce integration of rural economic layout,rationalization and upgrading of agricultural industrialization will become a reality.

In short, the information network service, is an important platform to promote rural connotation of city.

\section{Problems and Countermeasures of rural information service inthe network}


The survey found, many farmers in addition to occasionally see computer on TV, even never had the chance to meet a real computer, some even knowcomputer, but never used, not to mention the Internet, also do not talk to go upto use these tools to obtain the necessary information.

Aiming at the existing problems of rural information network service, we believe that can be addressed from the following aspects:

(1)Innovation of system. The division of urban and rural administrativemanagement system of rural economic and social backwardness, but also the root causes of rural information network service backward. To make ruralbackward modes of production and life style urbanization, we must start with the system reform started. At the macro level, the national administration mustnot conducive to reform the existing urban and rural development and the public goods supply system, ensure that farmers can equally owned property,education, employment, social security and personal development rights, inthe system to ensure the farmers enjoy the same rights information networkservice, improve efficiency through system innovation.

(2)Urban and rural public service. The center city and regional radiation as a whole, unified urban and rural land use, population scale, infrastructure construction, education development, ecological environment protectionplanning, especially in the construction of urban and rural transportation,communications and other regional infrastructure, should be based on internal \& external connection of urban and rural areas, intercommunication andconvenient principle, forming ensure traffic communication network of urban and rural production activities associated with the low cost, the employment ofurban and rural residents' consumption behavior and convenient life. Theoverall construction of urban and rural infrastructure, improving the sharingdegree of water and power supply, technical advice, technical training and culture education, market information, environmental protection and otherpublic services, change rural backward and closed state, thus promoting the urban and rural industrial and population fusion.

(3) increase in the construction of rural network platform of financial support.Multiple channels to raise funds, increase investment, strengthen the construction of network platform for rural.

(4)The establishment of the system, standardized management. All localities should according to the Ministry of agriculture to develop the "rural informationservice point that provisional measures" and "rural information qualificationcertification procedures", in combination with the local actual situation for the system and management measures.

(5)The training of high-level talent team of agriculturalinformation.

(6) community self-help mechanism. Community self-help mechanism with peasant association members raised funds to carry out self-help information service as the main feature, to take self investment, self service, self benefitform.

(7) the establishment of agricultural information service system perfect.

In short, the network information service to promote the traditional mode of agricultural production and the modernization of the traditional rural way of lifeof the community, is China change rural backward state, an important path to realize rural connotation of the city; the government should strengthen theinput, guidance and management, the construction of rural information network platform to promote the.

\section{References:}

(1) Wei Jie. The discussion of China city strategy (N) of the new choice. Guangming Daily, 2005-11-08 (6).

[2] Peng Guoli. Under the background of new rural construction of farmers' information literacy status and planning J. Search, 2006 (6). 
[3] To Ping, Li Xiao, Qiu Dunlian, Luo Zhongrong. A comparative study oninformation demand (rural areas with different economic development in China J]. Agricultural Library and information science, 2003 (6). 